Mark Sinclair, 'Bergson on Possibility and Novelty', Archiv für Geschichte der Philospohie (96/2, 2014) 
'Bergson on Possibility and Novelty', Archiv für Geschichte der Philosophie $(96 / 2,2014)$

Henri Bergson's 'The Possible and the Real' was published in Swedish in 1930 and then in French in 1934, and is based on a lecture delivered at the University of Oxford in $1920 .{ }^{1}$ In the essay, Bergson claims that the idea that "the possibility of things precedes their existence" [PM 109] is an illusion, a retrospective illusion, for our ideas of the possible, once correctly analysed, can be seen to arrive only after the fact: "the possible is merely the real with, in addition, an act of mind that projects its image into the past once it has happened" [PM 110]. The illusion is not innocuous, however, since it occludes the novelty and originality of each and every moment of experience. If an event was possible before it happened, Bergson argues, it would be merely the realisation of a predetermined programme, and nothing genuinely new would happen. Ideas that possibility precedes actuality are thus a function of an inability to admit "the continual creation of unforeseeable novelty" [PM 115].

Bergson insisted that the arguments of this short essay published late in his philosophical career are not peripheral or accidental to his thinking, but rather central to his philosophy as a whole. ${ }^{2}$ They certainly have been influential. They are of pivotal importance in the work of, for example, Gilles Deleuze, and within the recent renewal of interest in Bergson's thinking that Deleuze's approach has inspired. Other commentators, however, have drawn attention to limitations in Bergson's critique and pointed to difficulties in his

1 With the abbreviation $P M$ followed by a page number I refer to the original pagination of La pensée et le mouvant - the 1934 volume in which the essay 'Le possible et le réel' appeared - which is indicated in Bergson 1959 and Bergson 2009. The translations are based on Andison's in Bergson 1949.

2 See Benrubi 1942:366. 
conception of novelty. ${ }^{3}$ For all that, Bergson's critique has seldom been subject to critical analysis in relation to traditional conceptions of modality, and the sources and significance of his ideas about novelty have remained obscure. ${ }^{4}$ The present paper contends, in fact, that Bergson's critique of possibility and his ideas concerning novelty are bound up in his inheritance of a concept of genius. Both the critique of prior possibility and the affirmation of novelty are the expression of - to use a phrase I will clarify below - a 'metaphysics of genius', and only in recognising that and how they stand together as an episode within the history of the modern concept of genius, I argue, can they, and Bergson's philosophy as a whole, be adequately understood. ${ }^{5}$

The first section of the essay examines the specific sense of modality in question within Bergson's critique before showing how it depends on an idea of genius. Here, and in the following section, it will be important to determine how Bergson responds to the arguments of Gabriel Séailles in his 1883 Le génie dans I'art. ${ }^{6}$ The second section examines the problems that Bergson's critique of prior possibility poses in relation to his earlier work, the ambiguities in his conception of novelty, and how commentators have responded to these problems. The third section, however, addresses the particular and, in fact, positive conception of possibility that Bergson presents in 'The Possible and the Real'. Although he

3 See Jankélévitch 1959 [1931]; Chedin 1986; Mullarkey 1999; Gunter 2007.

4 Of the four studies listed above only Chedin 1986 makes a concerted attempt to situate Bergson's critique in relation to traditional conceptions of modality.

5 The present essay thus attempts to contribute to, as Philippe Soulez and Frédéric Worms (1997: 282) put it, Bergson's “entrée dans l'histoire", his admission as an important figure within the history of philosophy, which constitutes "une étape décisive pour son oeuvre".

6 Séailles 1883. 
maintains his critique of prior possibility, Bergson advances an idea - an idea that is too often neglected in studies of his thought - of the 'retroactivity' or future anteriority of possibility: an event will have been possible once it has occurred even though it was not possible beforehand. In the final section of the present essay, I argue that this reflection on time, tense and modality represents a new development in Bergson's thought that he is, nevertheless, unable to develop fully or explicitly precisely because he is tied to an idea of genius that he interprets, within the framework of a philosophical voluntarism, as a function of the will.

1. Against Prior Possibility: The Idea of Genius

According to Bergson, the idea of possibility, like those of nothingness and disorder, belongs to the set of "grand metaphysical problems" that are "generally badly posed and that can be solved when the statement of the problem is rectified" [PM 104]. If we ask about the ontological status of the possible, or about our epistemological access to it, whilst presupposing that the possible precedes the real, we will, Bergson claims, create insoluble philosophical problems and obscure the novelty that exists beyond the realms of predictable, repetitive events governed by causal law. These closed, determined realms are 'merely an abstraction' from the original truth of "concrete reality" [PM 110], from our life-world; the "system of science is extracted or abstracted from a whole which includes, beyond inert and unorganised matter, organisation" [PM 114]. These claims, it should be underlined, derive from Bergson's earlier work. In his Essai sur les données immédiates de la conscience (1889) Bergson had argued that real duration - our temporal experience - cannot be understood in deterministic or mechanical terms, and that no experience is qualitatively identical to another. Later, in L'évolution créatrice (1907), Bergson emphasises the ideas of novelty and of an open, unforeseeable 
future, and extends the scope of his claims to the whole of biological as well as psychological life.

Instead of reserving an idea of possibility for life beyond the realms of necessity, Bergson argues that if events were possible "they would be able to be represented in advance; they could be thought before being realised" [PM 110] and thus that nothing genuinely novel would occur in the event. Bergson does little, however, to clarify or categorise the particular sense of possibility at stake. Even though - and perhaps because - he claims to address an idea "immanent to most philosophies" [PM 112], he does not refer by name to any particular discussion of modality. He offers no account of the relation of representability or conceivability to possibility; ${ }^{7}$ he does not clarify whether representability or conceivability is to be understood in an imagistic sense, as a function of the imagination; and nor does he distinguish merely logical possibility - the absence of logical inconsistency - from metaphysical or physical (nomological) possibility. ${ }^{8}$ Nevertheless, at least the primary focus of his critique is clear: this is the paradigm of modality as alternative simultaneous possibilities that emerged in the $12^{\text {th }}$ century as a result of difficulties in reconciling Aristotle's 'statistical' paradigm of modality with the Christian conception of

7 I return to this issue, but in the edited summary of the 1920 Oxford paper that formed the basis of 'Le Possible et le Réel' Bergson does write (1972: 1324) that if something was possible, it was "par avance, plus ou moins vaguement représentable". For contemporary approaches to the issue of conceivability in relation to possibility, see King 2010 and Gendler and Hawthorne 2003.

8 According to the now 'standard' terminology, physical or nomological possibility is a matter of conformity to laws of nature, whereas metaphysical possibility is, more generally, a matter of conformity to the conditions of existence as such. In contemporary possible world semantics, $\mathrm{P}$ is metaphysically possible just in case $\mathrm{P}$ obtains in some possible world. 
creation. ${ }^{9}$ Such a sense of possibility is the basis of Leibniz's idea of the possible worlds arrayed before the infinite understanding of God, who, by virtue of his goodness, actualises the best among them; and, indeed, Bergson later stated that the target of his essay was, above all, Leibniz's doctrine. ${ }^{10}$ On this account, the possible is that which is conceivable without contradiction; a possible world is a maximal collection of compossible things; and the worlds thus possible already exist in the divine intelligence. For Leibniz's God, therefore, the future is wholly foreseeable, and, in a sense, it has already 'happened', even if His possible worlds are not, as they are for contemporary modal realists, real spatio-temporal worlds existing somewhere other than this one.

Against these claims, and presuming Leibniz's God not to exist, Bergson asks us to consider the future forms of literature: these are just as unforeseeable as was Hamlet in the $16^{\text {th }}$ century. There is nothing in the present state of art that allows us to determine what the original art of the future will be, and it is for this reason, when the work is brought about by a person of "talent and genius" [PM 110], that it is original. Hamlet was conceivable and thus possible only when it was written: "it is clear that the person in whom Shakespeare's Hamlet came forth in the form of the possible would have created in this way its reality; this would have been, by definition, Shakespeare himself" [PM 113]. If the work of the future were already possible, if I could conceive it, "I would", Bergson says, immediately "make it (je la ferais)" [PM 110]. In fact, I would already have made it, for "as soon as the musician has the precise and complete idea of the symphony he will create, his symphony has been created" [PM 13]. This is not to say, however, that Bergson has an idealist conception of creation according to which the artist first

9 See Knuuttila 1982 and Normore 2003.

10 See Benrubi 1942: 366: “'J'ai voulu, dit-il, réagir surtout contre Leibniz qui voyait dans le réel la réalisation du possible". 
has an idea of the finished product that she then realises in the work material, for as he had already written in 1907: "a free action or a work of art [...] can be expressed in terms of ideas only after the fact and in an approximate manner". ${ }^{11}$

To claim that the artwork of the future was not already enclosed "in some kind of cupboard of possibles" [PM 110] is not necessarily to claim that it was impossible. It certainly was not logically impossible, as is the contradictory idea of a square circle, and there was no "insurmountable obstacle" [PM 112] preventing its realisation. "This non-impossibility of the thing" can be thought as "the condition of its realisation", Bergson admits. Yet if we use the word possible to name such non-impossibility, adopting in this way Aristotle's most general definition of possibility, ${ }^{12}$ we should recognise that "the possible thus understood has no virtuality or ideal pre-existence ( $n$ 'est pas du virtuel, de l'idéalment préexistant)" [PM 112]. In this sense of possibility, for Bergson, it is a truism to claim that possibility is the condition of actuality, whereas in the other, stronger sense it is a pure illusion, for it would be tantamount to claiming that Shakespeare pre-existed Shakespeare himself [PM 112].

When exemplified in relation to the history of art, Bergson's argument may not be particularly demanding. If we accept the equation of possibility with conceivability, then the conclusion seems inevitable: original works of art, in their irreducible singularity and particularity, and thus in their novelty, are not possible before they occur. What is more, Bergson's claims concerning both possibility and novelty in the production of fine art are by no means

11 Bergson 1959: 684.

12 See Aristotle, Prior Analytics I, 13 32ª18-21. As Knuuttila (1982: 345) notes Aristotle uses this definition outside of strictly logical contexts (e.g. De caelo $281^{\mathrm{b}} 15$ 21). Whether or not Bergson understands this idea of impossibility in a sense more physical than mere logical inconsistency is a moot point. 
wholly novel, for Kant, it should be noted, seems to make comparable claims within the analysis of genius in the Critique of Judgment. ${ }^{13}$ Within art in general, as Kant writes, what is to be produced must first be "represented as possible [als möglich]"14 in the producer's mind, after which the physical process of production makes this representation actual. The design and conception of the product occurs according to a process of rational, conceptual deliberation and according to 'rules' which can be learnt and applied in different cases: in order to produce a table, one must select an appropriate material, the table itself must have a certain form etc. Fine and original art, in contrast, "does not permit of the judgment of the beauty of its product being derived from any rule that has a concept for its determining ground, and that depends, consequently, on a concept of the way in which the product is possible (wie es möglich sei)". ${ }^{15}$ In short, fine art production, as opposed to craft production, does not consist in the actualisation of a pre-given conceptual possibility.

Certainly, in Bergson's 'The Possible and the Real' there is no positive account of what in the artwork transcends the cold clarity of

13 References to Kant's Kritik der Urteilskraft follow the Akademie edition with volume and page. The translations are those of Walker in the Oxford edition (Kant 2007). Bergson does not, it seems, refer anywhere explicitly to Kant's analysis of genius in The Critique of Judgment.

14 Kant V: 307 . Note that if possibility here means anything more than mere logical possibility, then it is to be thought according to its determination in a narrower and more metaphysical sense as 'real possibility' within the Critique of Pure Reason: here the concept of a thing is possible "if it accords with the formal conditions of experience in general". Kant A220/B219. I use the common A/B form here to refer to pages of the first and second editions of Kant's Kritik der Reinen Vernunft. On Kant's early and later or 'critical' conceptions of modality, see Hintikka and Kannisto 1981.

15 Both quotations: Kant V 308. 
conceptual meaning that could be compared to Kant's doctrine of aesthetic ideas, and in this sense Bergson does not present, here or elsewhere, a developed aesthetic theory. ${ }^{16}$ In fact, rather than offer a theory relating only to a particular mode of experience, Bergson aims to extend his account of artistic creation in relation to the present and future of our lived experience in general: life is lived as a continual work of genius, as the continual irruption of "génialité", ${ }^{17}$ insofar as there is something qualitatively unique and original in every state of mind, in every moment of phenomenal experience, in every action. Early in the first chapter of Creative Evolution Bergson was relatively explicit about the importance of a conception of genius in his thinking, for he refers to Gabriel Séaille's Le génie dans l'art, which argues that "thought continues life" and that both can de described as the work - in differing degrees - of genius as a "creative power (puissance créatrice)". ${ }^{18}$ In fact, after stating that "one can say of life, as one can say of consciousness that at every moment it creates something", Bergson credits in a footnote the "double thesis" that "art prolongs nature and that life is creation" to Séailles' book on genius. ${ }^{19}$

16 For Bergson's recognition of the lack of a developed aesthetic theory in his work, see Benrubi 1942: 368. On this point see also Pilkington 1976: 142.

17 Bergson 1959: 634 : "Quant à l'invention proprement dite, qui est pourtant le point de départ de l'industrie elle-même, notre intelligence n'arrive pas à la saisir dans son jaillissement, c'est-à-dire dans ce qu'elle a d'indivisible, ni dans sa génialité, c'est-àdire dans ce qu'elle a de créateur'. Arthur Mitchell's translation of the term (Bergson 1911: 173) as 'fervour' occludes the connection to the idea of genius.

18 Séailles 1883 vii. All translations of this text in the present essay are my own.

19 Bergson 1959: 518-519. Note that in his 1904 discourse on the life and works of Félix Ravaisson (to whom Le génie dans l'art is dedicated) Bergson had already pointed to the unity of art and metaphysics: "Toute la philosophie de M. Ravaisson dérive de cette idée que l'art est une métaphysique figurée, que la métaphysique est une réflexion sur l'art, et que c'est la même intuition, diversement utilisé, qui fait le 
I will return to Séailles' book shortly, but the first illustration in 'The Possible and the Real' of this omnipresent genial novelty, an illustration that Bergson seems to present without irony, may be less than convincing: no matter how I envisage a meeting with colleagues beforehand, "the whole gives me a unique and new impression, as if it were drawn all in one go by the hand of an artist" [PM 99]. Bergson is, however, trying to convey the idea that novelty inhabits the most routine experiences, without denying the reality of that routine. There are aspects of our own experience and actions, he argues, just as there are aspects of original art, which consist of rule-bound repetition. If the artist is to produce something other than original nonsense, the wings of genius, as we might say, have to be clipped by taste, schools and technique; and this technique, mere "repetition", as Bergson notes, "concerns above all what the work will have in common with others" [PM 103]. In the same sense, in the course of our everyday lives we have every interest in following rules and regulations, and in contracting habits of effective action. Although Bergson often evaluates such habits and social rules negatively as stifling creativity, they do, viewed more positively, facilitate and provide a ground for novelty: "there will be novelty in our acts only thanks to what we have found to be of a repetitive nature in things" [PM 103]. ${ }^{20}$

Bergson evidently extends, in any case, his account of genius, and thus of possibility and novelty, from the fine arts to life in general, and this extension is precisely what is at stake in his philosophie profond et le grand artiste" [PM 266]. Keith Ansell-Pearson (2005: 70) signals the importance of this passage and of Bergson's reference to the work of Séailles, without, however, recognising how a conception of genius determines Bergson's reflection on art and his metaphysics as a whole.

20 These two different evaluations of habit do not alter Bergson's dualistic conception of it as other than, if not directly opposed to, a principle of freedom. On this point, see Renault 2004 and Sinclair 2011. 
'metaphysics of genius'. This extension does not entail that the meeting next week or my finishing a paper at home instead, are not possible. ${ }^{21}$ Bergson's position is rather that we have general ideas about such future contingencies - general ideas that are always inadequate to the singularity and particularity of experience - only on the basis of past experience, and thus that possibility here does not precede the real but rather arises from it. The implicit empiricist premise underlying this argument, according to which concepts or representations derive from experience, and not from, say, the productivity of the imagination, is certainly questionable. Yet for our purposes it is more important to note Bergson's diagnosis of the ultimate source of the "illusion" that possibility precedes actuality: through a covert and illegitimate form of pragmatism we import ideas "from the domain of fabrication" into "that of creation" [ $P M$ 107]. The idea of prior possibility derives from our prosaic concern with realising plans and goals, which can be instantiated many times over in different acts or products of the same form. Hence when we claim that the possible, i.e. a preconceived idea, precedes the real, we apply a schema proper to the domain of fabrication to the flux of life in general. In so doing we fail to recognise that these pre-conceived ideas are the result of an original act of creation, and that all of our particular acts and experiences are intrinsically different to those of the past. There is always, Bergson holds, an element of creation in our actions, even in those that may seem at first glance to be merely a choice between pre-existing options: "If I deliberate before acting, the moments of the deliberation offer themselves to my consciousness as the successive sketches, each

21 Thus Bergson offers not a negation of possibility, but a "quasi-négation"; Chedin, 1986: 36. In this sense Bergson's inquiry is limited to a concern for the origin or genesis of the ideas in modal propositions, and.he does not explicitly attempt to reduce talk of the possible to talk of the actual, as a present-day 'combinatorial' theory of possibility might; on the latter, see Armstrong 1989. 
particular in its own way, that a painter would draw of his painting; and the act itself, in being carried out, may well realise something desired and consequently foreseen, but it has nonetheless its own original form" [PM 100].

\section{Possibility and Potentiality}

If the illusion that possibility precedes reality just as a blueprint is prior to production is as tenacious as Bergson considers it to be, then the critique of possibility that he draws out according to a conception of genius is salutary. Despite the questionable empiricist premise underlying the argument and its lack of precision with regard to specific historical doctrines, Bergson's thinking offers an antidote to perhaps pernicious and persistent philosophical illusions. Much less salutary, however, is that Bergson seems to consider his critique of possibility in this narrow sense as a critique of possibility per se. The issue here is not that in the cases of metaphysical and physical possibility, conceivability can be only a guide and not a test for determining what is possible, given that some things may be conceivable and yet perfectly unrealisable in the world. Bergson does not, in point of fact, explicitly endorse a conceivability test for possibility, and states only - in the 1920 version of the paper - that for something to be possible it must be "in advance, more or less vaguely representable". ${ }^{22}$ The issue, then, is not the thought that conceivability is a sufficient condition for possibility, but rather the thought that it is a necessary condition. For according to a paradigm of possibility as grounded in powers or potentialities, the fact that our preconceptions are inadequate to the novelty of events does not entail that those events were not possible before they occurred. The particular form of a novel work of art in a block of marble may well have been unforeseeable, but we can still argue that the stone was

22 Bergson 1972: 1324. 
the statue in potentia, that the powers of the stone, along with the capacities of the artist, are what made the statue possible. We can certainly admit with Bergson that conceptions of what something can possibly be arrive after the fact, in the event, but this epistemological delay by no means necessarily entails the nonexistence of prior possibility as potentiality. ${ }^{23}$

Bergson's critique of prior possibility, then, applies only to a particular, intellectualist conception of possibility. Of course, one might imagine that elsewhere, in order to dispense with all forms of modal thinking, Bergson criticises and rejects any metaphysics of powers or potentialities - but he does not. On the contrary, many of his ideas concerning time as duration - such as the evolution of life as the progressive realisation of the élan vital in 1907 - seem to develop or at least require some sort of metaphysics of powers. In this connection, Pete Gunter has recently claimed that the arguments in 'The Possible and the Real' should not be "taken at face value", and that Bergson's approach presupposes a more positive conception of possibility. For "it would seem to follow" from Bergson's argument "that there exists no inherent relation between the past and present" ${ }^{24}$, whereas in all of his major works Bergson had affirmed, in different ways, that duration involves precisely such a relation. It should be underlined, however, that in and of itself Bergson's critique of possibility concludes only that there is no relation between the present and the future that is conceivable in advance, and not that there is no relation between them at all. It is

23 For a defence of Aristotle's conception of the possible as potentiality against Bergson's critique, see Chedin 1986. Chedin's arguments serve to challenge (although he does not refer to them) Hannah Arendt's assumption that Bergson's account of possibility is automatically a compelling critique of ideas of potentiality; see Arendt 1978: 31.

24 All three quotations: Gunter 2007: 34. 
only his accompanying affirmations concerning novelty in the essay that constitute, in effect, such a denial.

Indeed, when Bergson articulates an early version of his argument concerning possibility in the footnote of the first chapter of Creative Evolution that refers to Le génie dans l'art, he in no way contradicts Séailles' basic thesis that art "does not break the continuity of spiritual phenomena". ${ }^{25}$ Séailles had emphasised that the genius borrows the 'elements' of her work from experience of the world and from history; originality does not emerge ex nihilo and is already involved in the artist's selective perception and historical awareness. ${ }^{26}$ Bergson certainly qualifies this position, but he denies only that creation is a synthesis of pre-existing, separable elements, for this would be to admit that "their synthesis would have been given virtually, being merely one of its possible arrangements", and that a superhuman intelligence would have been able to apprehend this synthesis "in advance". At least in the domain of life, the 'elements' - and Bergson is so far from denying an inheritance from the past in the present that he finds it possible to continue to use the term in a positive sense - "have no real and separate existence". ${ }^{27}$

It is not simply the case, however, that in 1934 Bergson attaches affirmations of novelty to his treatment of possibility, whereas in 1907 he had not. The issue is rather that the idea of novelty can take on different accents in his work. On the one hand, novelty in an epistemological sense means only unforseeability, which does not preclude an intrinsic relation of past and present. This sense of novelty - which seems to predominate in Bergson's earlier work,

25 Séailles 1883152.

26 See Chapter V of Séailles 1883 for his argument concerning the pre-existing elements appropriated by genius.

27 Bergson 1959: 518-519. 
particularly when he is discussing biological evolution - is compatible with 'maturation'. ${ }^{28}$ On this basis, 'creation' as the principle of the production of novelty can be understood such that the idea of a 'creative evolution' is not a contradiction in terms. Yet, on the other hand, epistemological novelty often gives way to a more 'radical' or 'absolute' sense of novelty, one implying complete discontinuity of the present with the past. This comes to the fore in Bergson's discussion of artistic - as opposed to natural - production, and particularly in 'The Possible and the Real'. ${ }^{29}$ In this way, creation - in a historically proper sense - means production of an absolute novelty, and thus production ex nihilo. ${ }^{30}$ Certainly, some caution is required here, for Bergson argues that nothingness, like possibility and like disorder, is a mere en rationis supervenient on reality. ${ }^{31}$ Yet insofar as he holds - as we will see more clearly below - that creation results from a position transcendent to time and history it is radically de novo, and thus ex nihilo in the sense that it emerges from no existent thing other than the creative subject herself. ${ }^{32}$ It is true to say, as Stallknecht put it in an important study of 1934, that

28 See Bergson 1959: 503, a passage that I discuss in the following note.

29 Bergson does not himself adequately clarify the difference between these two senses of novelty, and they are both present already in 1907. In L'évolution créatrice (Bergson 1959: 503), immediately after having stating that durée means "invention, création de formes, élaboration continue de l'absolument nouveau", Bergson writes of "un travail intérieur de maturation ou de création", as if maturation and creation were synonymous.

30 We should recall that in the Renaissance creatio and creare were still only very rarely used to describe human, in contrast to divine production, and that the usage became common in the $17^{\text {th }}$ and $18^{\text {th }}$ centuries within the same movement of thought that led 'genius' to be posited as an irrational talent of the fine artist; on this history see Zilsel 1972 and Nahm 1947.

31 Bergson rehearses these arguments at the beginning of 'Le possible et le réel'. 
"Bergson's philosophy really contains two accounts of creation"33, and yet it is unhelpful to name these the 'irrational' and the 'esthetic'. For the 'irrational' idea of the production of an absolute novelty is already 'esthetic' insofar as it is influenced by a particular - and theologically inspired - interpretation of fine art production that came to the fore in the $17^{\text {th }}$ and $18^{\text {th }}$ centuries.

It was, it would appear, precisely in order to account for the first, less radical sense of novelty and creation that seems to predominate in Bergson's earlier work that in 1930/31 Vladimir Jankélévitch argued that his thinking presupposes an unspoken idea of "organic possibility (possibilité organique)". Organic possibility is that from which the present event emerges, and it is to be distinguished from mere logical possibility as a "promise" is distinguished from "permission". ${ }^{34}$ As a promise, it is "an élan or drive towards the concrete", and yet "a mystical indetermination, rich, profound and sonorous like the silence of the night". ${ }^{35}$ It is not a set of distinct 'possibles', ghostly proto-things striving to be actualised, but a primal state of interpenetration from which beings emerge in the forward thrust of life. Organic possibility, on this account, is in one sense nothing; it is "nothing at present, but it will be". In another sense, however, it is not a pure nothing; "it is something, but it represents in a compressed state an existence that in its adulthood will blossom freely". For Jankélévitch, this organic possibility characterises all those "nascent states that Bergson excels in describing", ${ }^{36}$ and it accords with Bergson's basic

32 For this terminological distinction between ex nihilo and de novo, see Mullarkey 1999: 137.

33 Stallknecht 1934: 53.

34 Jankélévitch, 1959: 217. All translations from this text are my own.

35 Jankélévitch, 1959: 218.

36 All three quotations: Jankélévitch, 1959: 217. 
idea that in 'creative' processes new forms emerge by means of dissociation and division, and not through any process of rearrangement of already distinct elements.

It should be noted, however, that Bergson had already read the manuscript of Jankélévitch's book before having his essay translated into Swedish in 1930. ${ }^{37}$ Despite the warm, congratulatory letter he sent to Jankélévitch, it may seem, therefore, that Bergson did not think the claims concerning 'organic possibility' worthy of development. This context may also seem to justify the approach of another important study, namely Gilles Deleuze's Le bergsonisme. Given Bergson's apparent antipathy to any conception of possibility, perhaps the only option available to us in order to preserve the integrity of his thinking as a whole is to attempt to establish a distinction between the possible, including any ideas of organic possibility or potentiality, and the virtual. The two terms 'possible' and 'virtual', which are traditionally synonymous or at least closely related, are now to be deliberately distinguished. ${ }^{38}$ The realisation of possibility or even potentiality, Deleuze claims, involves reproduction of possibles that are somehow pre-existent, and thus marginalisation of un-realised possibles; the virtual, on the other

37 See Jankélévitch 1959: 2. Bergson's letter to Jankélévitch is available in Bergson 1972: 1495. Pete Gunter (2007: 35) does not recognise this - inconvenient - historical fact when he appeals to Jankélévitch's arguments concerning 'organic possibility' in order to address the problems posed by Bergson's critique.

38 On this traditional synonymy see Lalande 1988 [1926]: 1211: “d'une manière générale, est virtuel ce qui n'existe qu'en puissance et non en acte ; mais cela peut s'entendre en deux sens : A - Au sens faible: qui est simplement possible en un certain sujet (comme le bloc de marbre qui est 'dieu, table ou cuvette'). Cette acception est rare. [...] $\mathrm{B}-\mathrm{Au}$ sens fort : qui est déjà prédéterminé, quoique cela n'apparaisse pas au dehors, et qui contient toutes les conditions essentielles à son actualisation". 
hand, must create its own lines of actualisation in positive and genuinely novel acts. ${ }^{39}$ Note, however, that although the essence of the argument is Bergsonian, the terminology is not: within the 1934 essay, as we have seen, Bergson uses the word virtuel, in a perfectly traditional way, as a synonym of possible. ${ }^{40}$ To construe Bergson as a philosopher of the virtual, as opposed to a philosopher of potentiality or possibility, is not only to interpret a philosopher as saying what he does not say, but also to read that philosopher as saying the opposite of what, in 'The Possible and the Real', he does actually say.

\section{The Retroactivity of the Possible}

The difference between the interpretations of Jankélévitch and Deleuze is to some extent merely terminological, since both seem to accept the necessity - in order to understand Bergson's own work of providing a more positive account of modality than the critique of prior possibility in 'The Possible and the Real'. To say that the issue is terminological, however, is not to say this terminological choice is unimportant, for opposing the 'virtual' to the 'possible', as if the meaning of the latter were perfectly univocal, risks alienating us from the philosophical tradition. Moreover, it risks blinding us to the positive conception of possibility that Bergson does, in fact, advance in the essay. Already in the version of the paper delivered in Oxford 39 Deleuze 1966: 100.

40 Both examples: PM 112. Deleuze's sleight of hand on this synonymy in 'Le possible et le réel' usually goes unnoticed amidst the contemporary enthusiasm for Bergson as a thinker of the 'virtual'. See Moore 2012:411-418 for a recent example of this. John Mullarkey, however, does note that Bergson often uses the term virtual as a synonym of the "illusory possible" (Mullarkey 2004: 483) and thus that "no clear water exists in Bergson's texts between the virtual and the possible as it does in Deleuze's reading" (Mullarkey 2004: 492). On this point, see also Chedin 1986: 38. 
in $1920,{ }^{41}$ Bergson argues that although it is nothing at present, possibility nevertheless will be. Although the event was not possible before it happened, it will have been possible once it has happened. The idea of the possible is therefore admissible if we accept that the possible is not a kind of presence, but rather a certain kind of future anteriority. We might ordinarily think that a present that becomes past becomes a necessity, because now we can do nothing about it, but here Bergson claims that the past is the realm of possibility insofar as the present puts it there. He recounts a conversation with a journalist:

'Let a man of talent or genius come forth, let him create a work: it will then be real, and by that very fact it becomes retrospectively or retroactively possible. It would not be possible, it would not have been so, if this man had not come upon the scene. That is why I tell you that it will have been possible today, but that is not yet so.' [...] 'That one can insert the real into the past and thus operate backwards in time, this I have never proposed. But there is no doubt that the possible can be lodged in it, or rather that the possible comes to lodge itself in it...' [PM 111].

Although Nietzsche had already articulated an idea of the retroactivity of the present on the past, Bergson's brief remarks on this point are certainly new in the sense that nothing in his earlier reflections on time explicitly prepares us for them. ${ }^{42}$ Yet the remarks

41 See Bergson 1972:1322-26. Of the commentators already mentioned, only Jankélévitch considers Bergson's doctrine of retroactivity to be worthy of extended discussion. However, even though Jankélévitch claims that Bergson developed this doctrine in response to reading his manuscript in 1930 (Jankélévitch 1959: 2), he does not address the problems - which I delineate below - attendant on the doctrine itself.

42 See Friedrich Nietzsche III: 404 (references to Nietzsche's work follow the Kritische Studienausgabe with volume and page): "Historia abscondita. - Jede grosse Mensch hat eine rückwirkende Kraft; alle Geschichte wird um seinetwillen wieder auf die Wage gestellt, und tausend Geheimnisse der Vergangenheit kriechen aus ihren Schlupfwinkeln - hinein in seine Sonne. Es ist gar nicht abzusehen, was Alles einmal noch Geschichte sein wird. Die Vergangenheit ist veilleicht immer noch wesentlich 
amount to much more than a fleeting observation, since the idea of retroactivity is developed in the introduction to La pensée et le mouvant, the volume in which 'Le Possible et le Réel' first appeared.

Here Bergson illuminates the idea with another example from the history of literature. Classicism offers itself now as a precursor of the romanticism of "a Rousseau, a Chateaubriand, a Vigny", but the "romantic aspect of classicism emerged only by the retroactive effect of romanticism once it appeared" [PM 16]. This aspect did not exist before romanticism, but, "retroactively", the latter "created its own pre-figuration in the past and an explanation of itself by its predecessors" [PM 16]. Romanticism, that is, created its own precursors. ${ }^{43} \mathrm{~A}$ novel work of art or literature allows us to view the tradition in a different way, and it is for this reason that original artists and writers, some time after the 'shock of the new' has receded, find themselves faced with accusations that their ideas were already there, like fruit ready to be picked, within the tradition. These accusations are expressions of what Bergson now terms the "retrograde movement of truth" [PM 1] insofar as they presuppose that the novel element was there all along and that, if anything has changed at all, it is merely our view of things. This is, Bergson claims, a "natural tendency" of the human mind that is no less an "error" and an "illusion", the "mirage of the present in the past" [PM $15]$.

unentdeckt! Es bedarf noch so veieler rückwirkender Kräfte!”.

43 Bergson is referring to E. Deschanel's Le Romantisme des Classiques (Deschanel 1882), as Robinet points out in Bergson 1959: 1574. As Jorge Luis Borges will write (and I am indebted to William Large for this reference) in 1951, referring not to Bergson but to a 1941 essay by T. S. Eliot: "The fact is that every writer creates his own precursors. His work modifies our conception of the past, as it will modify the future" (Borges 1964: 201). This is to say that all creative art and writing, as Pierre Bayard has put it, is Le Plagiat par anticipation (Bayard 2009). 
This illusory retrograde movement, then, accompanies the retroactive operation of the present on the past insofar as we think that an original work of art was possible, not just after it has occurred, but before it occurred. It is crucial to remark, however, that now Bergson thinks possibility - however inchoately - in a sense that goes beyond conceivability without contradiction. Although, after the fact of romanticism, it is true that classicism made romanticism possible, Bergson does not want to claim that now it is true that classical authors already had in mind, or could have had in mind, what is essential to romantic literature. Instead, possibility now seems to be thought as a quality of real, historical things, of works of art themselves: ${ }^{44}$ in classicism, romanticism makes present "a certain aspect" or "slice (découpure)" [PM 16] that did not previously exist, and which constitutes the possibility of romanticism itself. Possibility is no longer 'ideal pre-existence', but rather the future anteriority of a certain reality. In this way, however, Bergson risks conflating actuality with possibility. For it is not simply the possibility of romanticism that romanticism creates in classicism. This is certainly true in a sense, but in creatively deforming history, romanticism makes new aspects visible, i.e. actual in the extant works of classicism. That is, the original artwork produces its 'actual' precursors and not its possible ones. The

44 It is according to this idea of the retroactivity of the possible that Bergson seems to move from an essentially logical conception of possibility as non-contradiction to a more physical or metaphysical - and still less clearly defined - sense of possibility. As Mullarkey has it, Bergson conflates "logical possibility with metaphysical possibility" (Mullarkey 1999: 173), particularly in his discussion of the colour orange not being composed of yellow and red in a world where there exists, as of yet, only the colour orange. Once the composition has been discovered, our "habitual logic", Bergson claims, "cannot prevent itself projecting into the past, as possibilities or virtualities, present realities" [PM 19]. Yet the possibilities in this instance are not thoughts, but rather realities, i.e. red and yellow previously existing. 
romantic slices or aspects of classicism made present by romanticism are not just possible but well and truly actual. It now seems, in the introduction to the volume that Bergson wrote after 'The Possible and the Real', that he no longer considers it extravagant, as he did in the essay, to claim that the real can be inserted into the extant works of the past.

Another issue follows from this. On the one hand, Bergson seems to maintain that the new aspect revealed in classicism by romanticism did not previously exist in any sense at all, even though he advances the idea with a verb in the conditional: the aspects "could be additions of new qualities, created from scratch (de toutes pièces) and absolutely unforeseeable; and consequently an aspect (côté) of the present exists as an 'aspect' only when our attention has isolated it" [PM 15]. On the other hand, if Bergson really does think these aspects are created 'from scratch', one wonders why he uses the verb isoler in the last sentence, and then both a reflexive verb in a passive sense, se dégager, and a noun, découpure, with privative prefixes to describe the action of the present on the past: the découpure or 'cutting' s'est dégagé, was revealed in, or "lifted out of" as Andison has it, classicism by romanticism. ${ }^{45}$ Bergson could have phrased the matter quite differently, using different words to express an idea of the present simply putting something in the past, or imposing something on it. The fact that he does not could be taken as a residual expression of the retrospective illusion that he otherwise criticises. Yet it seems that this is much rather an expression of the difficulties of his own 'creationist' position. He considers explicitly only two alternatives: either the aspect was already and actually there in the work of the past or it is created in it

45 See Bergson 1949: 23 and PM 15-16. In the new critical edition of La pensée et le mouvant, Arnaud François (Bergson 2009: 314) feels it necessary to underline that these 'découpures' are in fact created, but he passes over in silence the tensions involved in such a claim and does not clarify the sense of creation itself. 
by the work of the present. Yet Bergson's own apparent hesitations indicate that the latter conception is hardly convincing enough to combat the allegedly illusory attractions of the former.

Bergson's official doctrine, then, seems to be that the new aspect is imposed on the tradition and that it is thus created 'from scratch'. It is instructive to note that in this way Bergson has - consciously or otherwise - come to reject, rather than merely qualify, Séailles' thinking in Le génie dans l'art. According to his continuity thesis, Séailles had claimed that "the imagination" - genius, in other words - "does not create, in the strict sense of the word; it does not produce new forms from scratch (créées de toutes pièces)". ${ }^{46}$ In taking up this phrase within his reflection on retroactivity, Bergson seems to affirm, pace Séailles, the absolute spontaneity and creative power of the artist, at least as a hypothesis: not only has the artist the ability to produce new forms in the present, she also has the power to create them in the works of the past.

A third issue in Bergson's conception of retroactivity concerns the extension of his 'creationist' doctrine - in Séailles' strict sense of the term 'creation' - in the theory of art to the movement of history in general. The idea of fine art as the product of an unconditioned genial subject is now, after a few centuries, a commonplace, but the extension of this idea - within what I have called Bergson's 'metaphysics of genius' - to social development more broadly understood is much more challenging. Bergson writes that nothing in the present state of society allows us to understand what it will become, and that the precursory signs of the future in the present will become retroactively apparent only when that future has arrived [PM 17]. ${ }^{47}$ It seems difficult to consider this picture of history without 46 Séailles 1883: 154.

47 “The premonitory signs are therefore, in our eyes, signs only because we know the course, because the course has been completed. Neither the course, nor its direction, nor in consequence, its end were given when these facts came into being: hence they were not yet signs" $[P M$ 15]. The political consequences of such a doctrine of 
movements, tendencies or social forces as anything other than a description of societal evolution as perpetual revolution. Bergson's critique of possibility certainly derives from his concern in L'essai to overturn conceptions of freedom as the operation of a libre arbitre selecting from a-temporal possibles. Yet, on the evidence of his treatment of social history here, the principle of human action and freedom is itself extra-historical. To be sure, Bergson admits in a parenthesis that "not just any (non quelconque)" [PM 15] novel reality is able to emerge from a specific point in history. Yet this only gives rise to the question of the nature of the 'link' between the past and future, and of what there is in the past that allows only certain forms of the future. In other words, Bergson does not explain why the idea that nothing is possible before it happens does not amount to the claim that everything is, in the end, possible.

Finally, whether it concerns a retroactivity of the possible or of the actual, and whether it concerns an imposition on or rather a revelation of works of the past, the general idea of the retroactive action of the present on the past remains as a mere affirmation in Bergson's work. In response to the claim that the possibility of romanticism always resided in classicism, and that previously we were just unaware of that fact, Bergson, in the end, only exclaims, and can only exclaim, that the possibility, i.e. an actual aspect, was put there by romanticism. The problem here is not simply the lack of a positive account elsewhere in Bergson's work of how such retroactivity might operate. Just as important is the fact that this conception of retroactivity contrasts with the idea of 'pure memory'

\footnotetext{
historical action without conditions are clear: it would lead either to a quietism, since radical change will happen regardless of what we do, or to a voluntaristic 'putchism' that attempts to achieve change without regard to present social conditions. Whether, and the extent to which, this conception of history and novelty informs later French philosophies of history and of the 'event' is not an issue that it is possible to address adequately here.
} 
advanced in Matter and Memory. There Bergson had argued that the past is a kind of reservoir existing in-itself that is made present - in different ways and to different degrees - in experience by means of perception, recognition, explicit recollection and dreams. Now the claim is - in thinking about the past from the perspective of social, cultural and collective history, rather than from that of individual memory - that in some sense the very nature of the past is a function of the 'creativity' of the present open to the future.

\section{Conclusions: Genius and the Will}

Bergson's philosophy of duration, as we have seen, requires a more positive conception of modality than the critique of prior possibility involved in his inheritance of a concept of genius. This has not gone wholly unnoticed by commentators, and both Jankélévitch and Deleuze have attempted, in different ways, to articulate a positive modal thinking that would accord with Bergson's ideas. Within his discussion of retroactivity, however, the idea of possibility indeed takes on a positive and a more physical or metaphysical sense, insofar as it is no longer simply a function of what can be thought, but of a certain quality of real, historical things themselves. On this sense of possibility, Bergson's 'official' position is that it is created in the past by the work of the present - and yet he also seems drawn to the idea that it preceded the present work, but not, to be sure, as an ideal possible. Bergson seems drawn, in other words, to the idea that possibility in this non-ideal sense is neither simply prior nor simply posterior to the present, but somehow both at the same time.

How to make sense of such a position? It implies, of course, that the past is integral to the creative process. Furthermore, and to remain with the paradigm of artistic creation, it seems to imply that canonical succession is constituted by a reciprocal play between present-day genius and the exemplarity of past works. This 
exemplarity would certainly be determined by the genius who selects the work as a model, but that canonical work would at the same time have to inspire this repetition. Hence the genius and the exemplary work are essentially related; the one is nothing without the other. The original work in the present thus emerges not ex nihilo, but rather ex historia, and yet this is not to say that the possibility of the original work simply pre-existed the present in the great work of the past. Bergson seems to point towards the idea that the original work reveals what the past made possible - and that this possibility is nothing without the original work in the present. On this basis, it would be fruitless to wonder whether the possibility of the work chronologically precedes its actuality or vice versa, for both arrive together and co-constitute the 'shock of the new'.

If Bergson's thinking does point in this direction, his later work would stand in a hitherto unnoticed proximity to the 'hermeneutic' conceptions of possibility, temporality and history advanced in the $20^{\text {th }}$ century by Martin Heidegger amongst others. ${ }^{48}$ Yet Bergson never comes to reflect on a form of historical repetition that would be something other than the 'mere' repetition, the 'boring' (if not necessarily 'bad') repetition of the same that he describes in 'The Possible and the Real'. This is a function of his attachment to an idea of radical and absolute novelty, an attachment which, to be sure, is both epistemologically and ontologically problematic. If the present is as radically or absolutely new as Bergson claims, one wonders how we could recognise it to be so, particularly given that as he had argued in 1896 - memory, and thus the past, conditions re-cognition and perception in general. ${ }^{49}$ Furthermore, such a radically new present would reduce the movement of time to a mere succession of disconnected moments, and it thus would return us to 48 See Heidegger 1984.

49 On this point see Mullarkey 1999: 135-137. 
the sort of 'cinematic' conception of movement that Bergson criticises so compellingly in $1907 .^{50}$

Bergson is certainly led to an idea of novel discontinuity through his inheritance of a modern conception of fine art production as the work of genius, and, in the end, he seems unmoved by Séailles' attempt to perceive in genius a principle continuous with nature and history. It is necessary to ask, in conclusion, why this is so. The final paragraphs of 'The Possible and the Real' adduces three distinguishable but connected ethical motivations for Bergson's positing of radical novelty. First, Bergson suggests that a doctrine of novelty can guide a way of life from which we can gain "greater joy" [PM 116]. Recognising the novelty in experience, he argues, would allow us to break the spell of the monotonous repetition of the same dulling our sensibility, and thus it would allow those who do not have easy access to original art to share in the joy of those who do. Now, if novelty is a source of joy, then one can understand why Bergson might seek its purest form in asserting the existence of a present absolutely and radically new. It is, however, certainly not unreasonable to wonder whether such an assertion of novelty as good per se ultimately amounts to an absurd ethical prescription, one that is interesting only to those, without a fixed purpose in life, suffering from ennui. ${ }^{51}$ Bergson seems not to have considered that

50 See Chedin 1986: 48.

51 Bergson's remarks about novelty here confirm the suspicions that Stace (1939: 296-297) voiced in 1939 within an attempt to clarify the "vague fog of ideas connected with the concept of novelty as that concept is found in the writings of such authors as Bergson, William James, Samuel Alexander": "I cannot rid my mind of the impression that these philosophers vaguely and absurdly suppose that novelty is something per se desirable. Is it possible that they are influenced by that thirst for change for its own sake, for excitement, for thrills and surprises, which is apt to consume men who have no serious purpose in their lives, men who in consequence suffer from ennui?". 
different evaluations of novelty are possible, or to have read the rather more negative one advanced in Søren Kierkegaard's Repetition: "Who could want to be susceptible to every fleeting thing, the novel, which always enervatingly diverts the soul anew?"52

A second, more philosophically defensible motivation for Bergson's attachment to an idea of radical novelty lies in the fact that he is, of course, a philosophical libertarian. The error of traditional philosophies of freedom, he claims at the end of the essay, is to have thought it in terms of pre-existing possibilities, for to do so is to let the necessitarian enemy through the gates [PM 115]. Bergson clearly has Leibniz's philosophy in mind here: Leibniz's appeal to possibilities - possibilities pre-determined in the divine intelligence - does not allow him to escape the necessitarian position that he finds in Spinoza. ${ }^{53}$ Now, we may certainly wish to question the specific form of Bergson's libertarianism, but is clear that a conception of 'absolute' novelty, of an absolute break from the past, makes philosophical room for it.

A third motivation for his emphasis on radical novelty is announced in the last lines of the essay: apprehension of novelty in our actions and experience in general will "above all" make us "stronger (plus fort)", "for we shall feel we are participating, creators of ourselves, in the great work of creation which is the origin of all things and which goes on before our eyes" [PM 116]. We will gain strength, Bergson argues, in recognising that our creative power is one with a more general creative power that underlies life and the movement of time as such. Hence: "humbled heretofore in an attitude of obedience, slaves of certain vaguely-felt natural necessities, we shall once more stand erect, masters associated with a great Master" [PM 116]. However, we are to understand exactly this invocation of a great Master in the penultimate 52 Kierkegaard 1983: 133.

53 For a classic statement of this interpretation see Chapter V of Lovejoy 1964. 
sentence of the essay, the goal of philosophical reflection and life itself is strength and mastery, as Descartes had already held, even if we can never gain a monopoly on this power. Consequently, with mastery posited as an ethical goal, and if creative novelty is a function of our own mastery, we can see why Bergson would posit a radical form of the former, for this heralds an increase in the scope of the latter.

Joy, freedom and mastery - and of the three, Bergson holds the third to be the most significant. The reason for this lies, perhaps, in the fact that Bergson's position is the expression not just of a will to mastery, but of a philosophy of the will tout court. For Bergson, art is the expression of a creative power that is not only extra-historical and purely subjective, but also voluntary. We are artistic when "we want to be (quand nous le voulons)" [PM 102], he writes, and this is not an inadvertent remark given that, as he claims in 1907, "the principle of all life" is "a pure willing (un pur vouloir)" ${ }^{54}$ If all creation is a willing, and all creation - as we have just seen Bergson assert is a self-creation then all creation is at bottom a 'will to will' - a willing that seeks, by means of its 'creative expressions', to increase its own power and mastery. We may certainly be able to find similar ideas in other thinkers of the $19^{\text {th }}$ and $20^{\text {th }}$ centuries, with Nietzsche foremost among them, but it is remarkable - and seldom remarked that in Bergson's thinking a philosophical voluntarism comes to occupy the void left by his rejection of the continuity of genius with history and nature.

54 Bergson 1959: 697. That the remark in 'Le possible et le réel' is not inadvertent is noted by Bouaniche in Bergson 2009: 385. On the question of the will in Bergson's thought, see François 2008. 
Ansell-Pearson, K. 2005. “Bergson's Encounter with Biology: Thinking Life". Angelaki 10/2: 59-72.

Arendt, H. 1978. The Life of the Mind. San Diego.

Armstrong, D. 1989. A Combinatorial Theory of Possibility. Cambridge.

Bayard, P. 2009. Le Plagiat par anticipation. Paris.

Benrubi, I. 1942. "Un entretien avec Bergson (Fragment de journal)". In

Henri Bergson: Essais et témoignages recueillis. Eds. A. Béguin and

P. Thévenaz. Neuchatel.

Bergson, H. 1911. Creative Evolution. Trans. A. Mitchell. New York.

- 1949. The Creative Mind, trans. M. Andison. New York.

- 1959. Euvres. Paris.

- 1991. Matter and Memory. Trans. N. Paul and W. Palmer. New York.

- 1972. Mélanges. Ed. A. Robinet. Paris.

- 2009. La pensée et le mouvant. Eds. Worms et al. Paris.

Bernstein, J. 1992. The Fate of Art. London.

Borges, J.-L. 1964. "Kafka and his Precursors" in Labyrinths. New York.

Chedin, J.-L. 1986. "Deux conceptions du possible: Aristote et Bergson". La revue de l'enseignement philosophique 37/2: 3650.

Deleuze, G. 1966. Le bergsonisme. Paris.

Deschanel, E. 1882. Le romantisme des Classiques. Paris.

François, A. 2008. Bergson, Schopenhauer, Nietzsche: volonté et réalité. Paris.

Gendler, T. and Hawthorne, J. (eds.) 2003. Conceivability and Possibility. Oxford.

Gunter, P. 2007. "Bergson's Creation of the Possible". Substance 36/3: 33-41.

Heidegger, M. 1984. Sein und Zeit. Tübingen. 
Hintikka, H. and Kannisto, H. 1981. "Kant on the 'Great Chain of Being'". In Reforging the Great Chain of Being. Ed. S. Knuuttila. Dordrecht.

Jankélévitch, V. 1959 [1931]. Henri Bergson. Paris.

Kant, I. 1902-. Gesammelte Schriften. Berlin.

- 2007. Critique of Judgment. Trans. N. Walker. Oxford.

- 2003. Critique of Pure Reason. Trans. N. K. Smith. Basingstoke.

Kierkegaard, S. 1983. Fear and Trembling/Repetition. Eds. Hong and Hong. New Jersey.

King, P. 2010. "Imagining as a Guide to Possibility". Philosophy and Phenomenological Research 81/3: 620-663.

Knuuttila, S. 1982. "Modal Logic". In The Cambridge History of Later Medieval Philosophy. Eds. N. Kretzmann, A. Kenny and J. Pinbourg. Cambridge.

Lalande, A. 1988 [1926]. Vocabulaire technique et critique de la philosophie. Paris.

Lovejoy, A. O. 1964 [1936]. The Great Chain of Being. Cambridge, Massachusetts.

Moore, A. W. 2012. The Evolution of Modern Metaphysics. Making Sense of Things. Cambridge.

Mullarkey, J. 1999. Bergson and Philosophy. Edinburgh.

- 2004. "Forget the Virtual: Bergson, Actualism and the Refraction of Reality". Continental Philosophy Review 37: 469493.

Nahm, M. 1947. "The Theological Background of the Theory of the Artist as Creator". Journal of the History of Ideas 8/3:362-372.

Nietzsche, F. 1988. Kritische Studienausgabe, ed. M. Montinari and G. Colli. Berlin.

Normore, C. 2003. "Duns Scotus's Modal Theory". In The Cambridge Companion to Duns Scotus. Ed. T. Williams. Cambridge.

Pilkington, A. 1976. Bergson and His Influence: A Reassessment. Cambridge. 
Renault, A. 2004. "Renault, 'L'habitude chez Bergson: une esquisse du concept phénoménologique de Stiftung ?', Alter 12: 79-103 Séailles, G. 1883. Le génie dans l'art. Paris.

Sinclair, M. 2011. 'Is Habit the "Fossilised Residue of a Spiritual Activity"? Ravaisson, Bergson, Merleau-Ponty'. Journal of the British Society for Phenomenology 42/1: 33-52.

Stace, W. 1939. "Novelty, Indeterminism and Emergence". The Philosophical Review 48/3: 296-310.

Stallknecht, N. 1934. Studies in the Philosophy of Creation with Especial Reference to Bergson and Whitehead, Princeton.

Zilsel, E. 1972 [1926]. Die Entstehung des Geniebegriffs - Ein Beitrag zur Ideengeschichte der Antike und des Frühkapitalismus. Hildesheim/New York. 